\title{
Evaluation of Stabilized Soymilk Prepared from Sprouted Soybean with Orange Flesh Sweet Potato Starch for Ambient Storage
}

\author{
Innocent Nwazulu Okwunodulu ${ }^{1, a,{ }^{, *}}$, Anselm Uzochukwu Onwuzurike ${ }^{1, b}$, \\ Alexzandria Obianuju Ochiogu ${ }^{1, \mathrm{c}}$, Comfort Ugochi Uzochukwu ${ }^{1, \mathrm{~d}}$
} ${ }^{l}$ Department of Food Science and Technology, College of Applied Food Sciences and Tourism, Michael Okpara University of Agriculture,
Umudike, Abia State, Nigeria
${ }^{*}$ Corresponding author

\begin{tabular}{|c|c|}
\hline R T I C L E I N F O & B S T R A C T \\
\hline $\begin{array}{l}\text { Keywords: } \\
\text { Sprouted soybean } \\
\text { Potato starch } \\
\text { Stabilization } \\
\text { Shelf stability } \\
\text { Ambient storage }\end{array}$ & 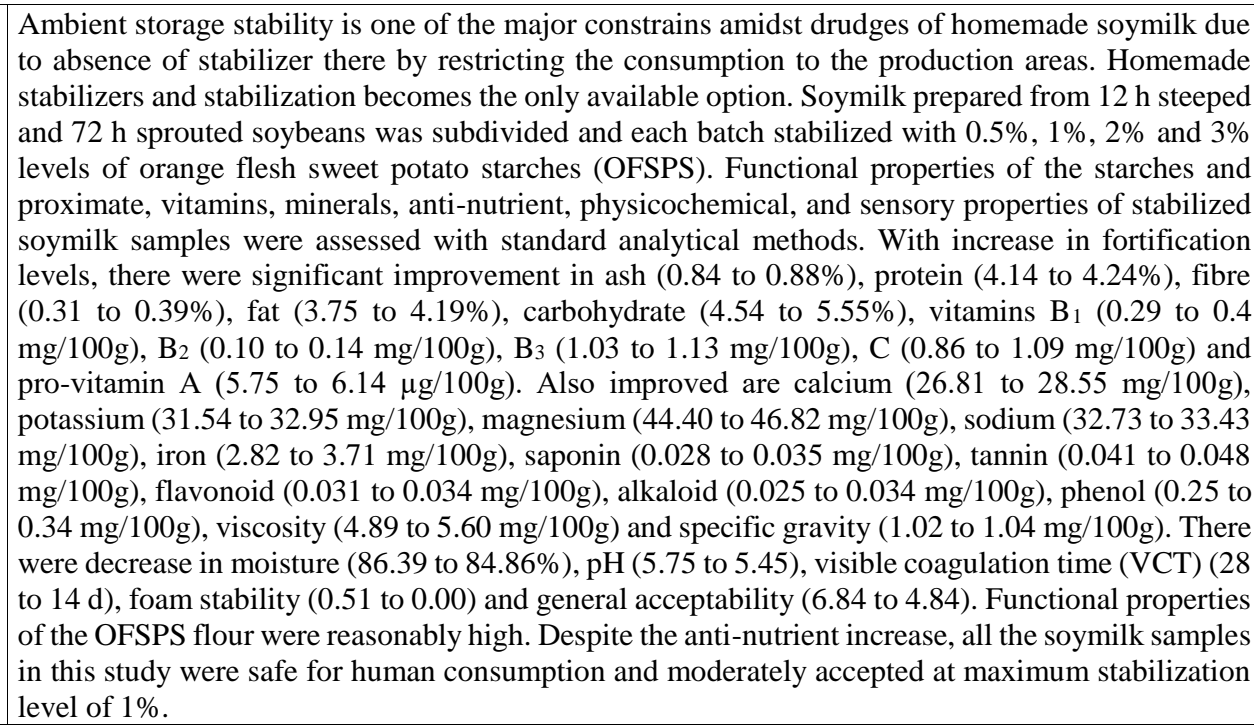 \\
\hline
\end{tabular}

\section{Introduction}

Soy milk is a stable emulsion of oil, water and protein plant-based drink produced from soybeans by steeping, boiling, dehulling, grinding, sieving and boiling. It originated as a by-product of tofu (bean curds) manufacture but was unpopular due to its flatulence and discomfort causing oligosaccharide to lactose in-intolerant adults. It was a staple of East Asian cuisine over the last few centuries, before it was discovered that prolonged heating eliminated the flatulence-causing constituent. Improved production techniques were developed thereafter to give it a taste and consistency more closely resembling diary milk along with similar vegetable-based milks like almond and rice milk. Soymilk flavour quality differs according to the cultivar of soybean used in its production (Smita et al., 2015). Other sensory qualities are mouth feel (smooth but thick), color (off-white) and creamy appearance resembling cow's milk (Kumar et al., 2003). Fresh soymilk has a very short shelf-life which limits its consumption within the production areas. Thermal processing is the most common practice used to improve the microbial safety and extend the shelf life of soymilk because it inactivates vegetative pathogen and many spoilage bacteria (Achouri et al., 2007). Use of ultra-high temperature is relatively new for soymilk production (Yuan et al., 2008).

Sprouting of soybean has been reported to increase protein content, reduce fat, trypsin inhibitor and phytic acid which reduction otherwise necessitates intense heating or ultra-filtration (Agrahar, 2014). Because sprouting is a natural, non-thermal, non-chemical process, it results in better quality milk with improved yield (Nsofor and Osuji, 
1997), good color characteristics and higher acceptability due to the absence of beany flavour and odour (Agrahar, 2014).

The orange flesh sweet potatoes (OFSP) (Ipomoea batata) are known good sources of vitamin A and energy (Bulean et al., 2008). The starch composes of about $1 / 4$ amylose and 3/4 amylopectin and is converted to maltose during cooking to give tasty and sugary product (Berski et al., 2011). The dominant vitamin A precursor in OFSP is beta-carotene. The OFSP is also an antioxidant, antiinflammatory food, excellent source of vitamin A and very good source of vitamin C.

Un-stabilized soymilk undergoes ambient storage changes due to interactions, coagulations and sedimentations that affect its physicochemical properties. Interactions and coagulation cause nutrient loss, $\mathrm{pH}$ changes, increase in total solids and viscosity. Sedimentation causes color decrease. (Jimoh and Kolapo, 2007; Okwunodulu et al., 2015). Soybean sprouting results in insignificant interactive effects on soymilk physicochemical properties. Appropriate and adequate addition of stabilizer, homogenization and vitamin $\mathrm{C}$ protection stabilize soymilk (Agrahar, 2014). Soymilk stabilization level of $0.5 \%$ had been reported (Jimoh and Kolapo, 2007; Joel and Guo-Nong, 2008). This study aimed at exploring the quality of stabilizing soymilk from sprouted soybeans with OFSPS for ambient storage.

\section{Materials and Methods}

\section{Material Procurement}

Soybean (Glycine max) (Picture 1) OFSP (Picture 2) were purchased from Ubani main market, Umuahia. Plant ash was gotten from empty palm bunch procured from a small scale oil mill in Ogbuebule in Ikwuano local Government Area, all in Abia State Nigeria.

\section{Sample Preparation}

\section{Preparation of Soymilk}

Soymilk was produced from sprouted soybeans according to Okwunodulu et al. (2017a) with slight modification. Cleaned and weighed $(5.5 \mathrm{~kg})$ whole soybean was soaked in clean tap water for $12 \mathrm{~h}$, drained and spread on a cleaned jute sack placed on a platform, few meters above the floor. The soybeans were sprinkled with water every 4 hours to initiate sprouting. Thereafter, water was sprinkled every 6 hours during the $72 \mathrm{~h}$ sprouting at room temperature in the dark. The sprouted soybean (Picture 3) was washed to remove odour and boiled with $30 \%$ plant ash solutions for 20 minutes drained, cooled to room temperature and dehulled manually. The hulls and shoots were removed by water floatation method. The dehulled soybean cotyledons were milled in QASA blender (model QBL-18L40) with hot water $\left(93^{\circ} \mathrm{C}\right)$ in a ratio of 1 $\mathrm{Kg}$ : 2.7 L respectively. The slurry obtained was sieved with a double muslin cloth, and the extract (soymilk) obtained was boiled in an open pan for 20 minutes and allowed to cool to room temperature (Figure 1).

Starch extraction

Starch was prepared following the method described by Eke-Ejiofor (2015) with slight modification. Orange flesh sweet potato roots of good quality were washed to remove soils and dirt, peeled using a stainless steel knife, washed again and disintegrated with a manual grater. The mash obtained was milled, mixed with water and sieved through a double muslin cloth to obtain starch solutions. The starch was separated from the water by sedimentation and decantation. The starch paste obtained was thinly spread on an oven tray and dried at $50^{\circ} \mathrm{C}$ for $24 \mathrm{~h}$ (Figure 2). Dried starch obtained was white, odourless and tasteless.

Plant ash production

Dried and sorted empty palm bunch was burnt to ash on a clean surface. Un-burnt materials were removed from the ash, milled thereafter and sieved with a fine sieve mesh to obtain a fine ash that was used for boiling.

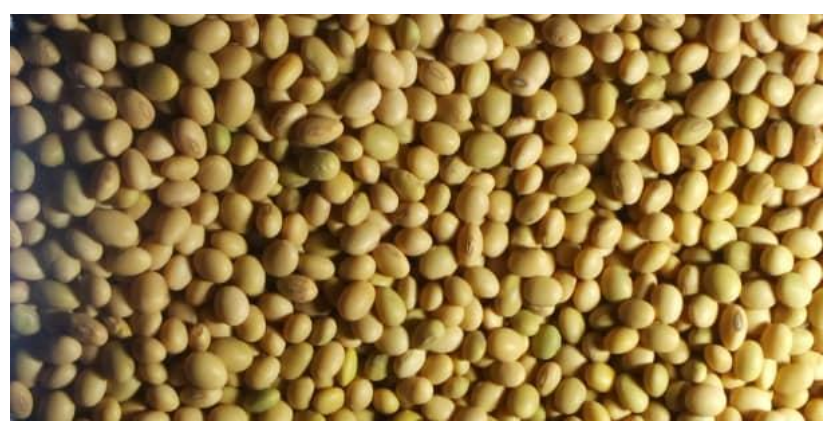

Picture 1. Un-sprouted Soybean

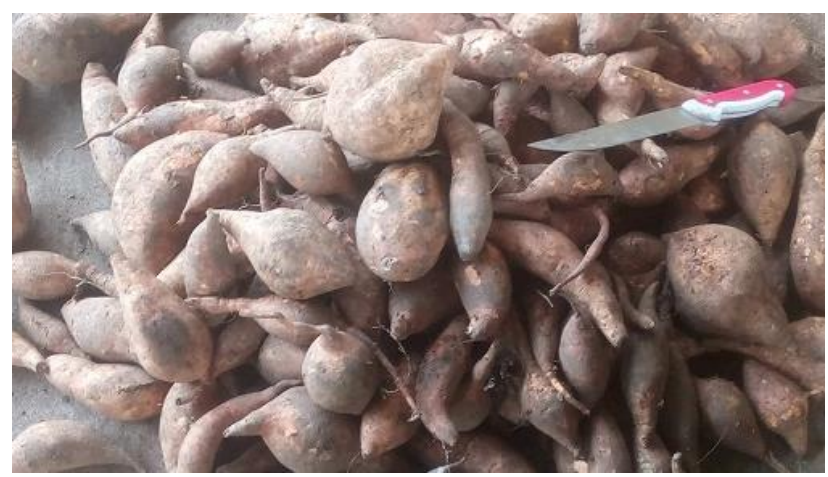

Picture 2. Orange flesh sweet Potato

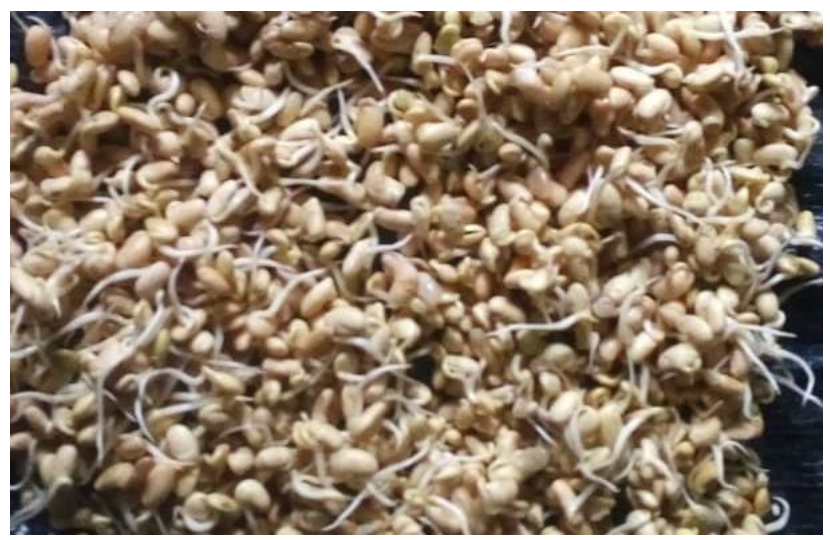

Picture 3. Sprouted soybean

\section{Starch extraction}

Starch was prepared following the method described by Eke-Ejiofor (2015) with slight modification. Orange flesh sweet potato roots of good quality were washed to remove soils and dirt, peeled using a stainless steel knife, washed again and disintegrated with a manual grater. The mash obtained was milled, mixed with water and sieved through a double muslin cloth to obtain starch solutions. 


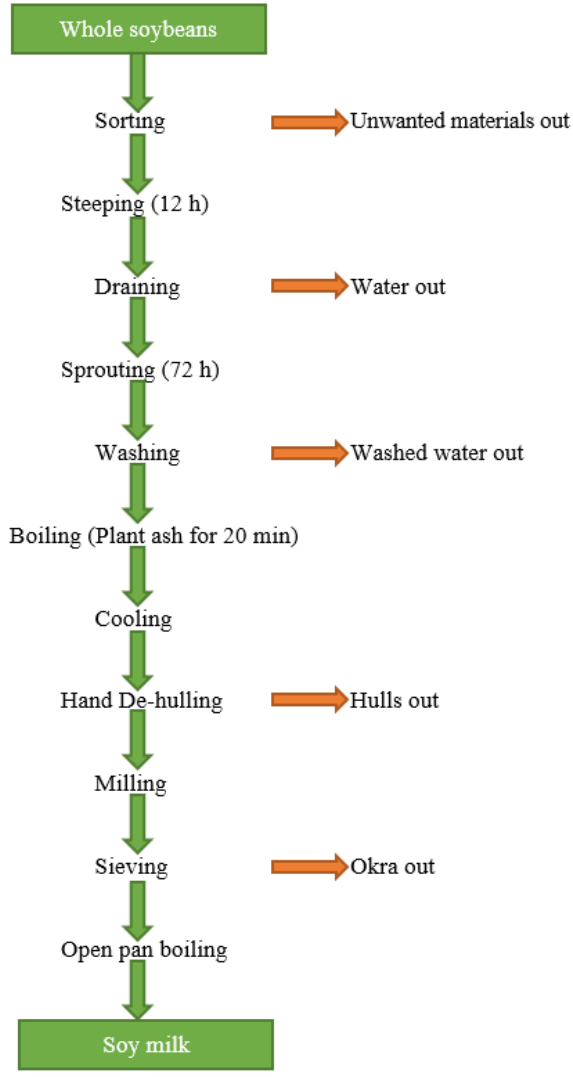

Figure 1. Flow chart for the production of soymilk from sprouted soybean (Okwunodulu et al., 2017a).

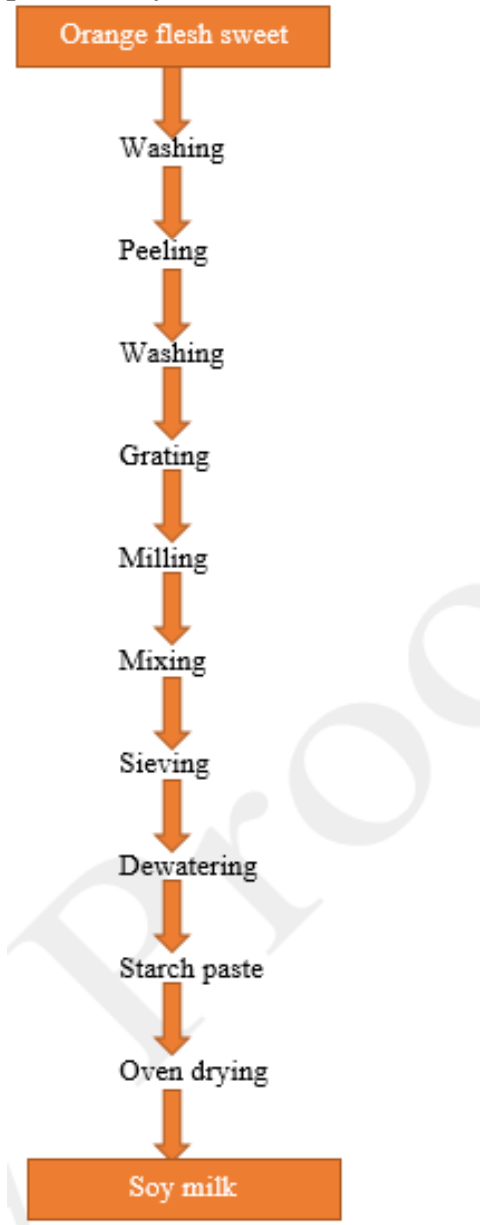

Figure 2. Flowchart for the production of Irish potato starch (Eke-Ejiofor, 2015).
The starch was separated from the water by sedimentation and decantation. The starch paste obtained was thinly spread on an oven tray and dried at $50^{\circ} \mathrm{C}$ for 24 h (Figure 2). Dried starch obtained was white, odourless and tasteless.

Plant ash production

Dried and sorted empty palm bunch was burnt to ash on a clean surface. Un-burnt materials were removed from the ash, milled thereafter and sieved with a fine sieve mesh to obtain a fine ash that was used for boiling.

\section{Stabilization of Soymilk}

The method described by Smita et al. (2015) with slight modification was used in stabilization of the soymilk. The soymilk bulk earlier produced was divided into five bathes, each which was stabilized with $0.5,1.0,2.0$ and 3.0\% respectively with OFSPS. Each stabilized batch was blended separately with variable kitchen QASA blender (model QBL-18L40), bottled, coded, sterilized in an autoclave $\left(121^{\circ} \mathrm{C}\right.$ for $\left.5 \mathrm{~min}\right)$, cooled and stored for analyses. The remaining batch served as control and underwent same process without stabilization.

\section{Analyses}

Proximate analysis

The method described by Onwuka (2018) was used in determining the moisture, fats, ash, protein, carbohydrate and fibre contents of the samples.

Anti-nutrient analysis

Gravimetric and acid hydrolysis methods described by Harborne (1973) were used for alkaloid and flavonoid determinations respectively. The method described by AOAC (2010) was used for saponin determination. Tannin was determined by the Folin-Denis spectrophotometer method described by Pearson (1976) and phenol was determined using method described by Oberlease (1973).

Vitamin analysis

Spectrophotometer method by Onwuka, (2018) was employed to determine vitamins A, vitamin $\mathrm{B}_{1}$ (Thiamin), $\mathrm{B}_{2}$ (riboflavin), $\mathrm{B}_{3}$ (niacin). The method described by Okwu and Josiah (2006) was employed in vitamin C determination.

\section{Mineral determination}

Calcium, iron and magnesium content of the soymilk were determined by complexiometric titration method of Onwuka (2018). Potassium and sodium were determined by flame photometry method described by James (1995).

Physicochemical analysis

The $\mathrm{pH}$ was determined by the method of Onwuka (2018). The AOAC (2010) method was employed to determine viscosity. Visible coagulation time (VCT) was determined by visual observation for obvious coagulation and phase separation method described by Okwunodulu et al., 2015). Here the milk was filled in transparent air-tight bottles, kept at ambient temperature on the shelf and observed for visible coagulation time (VCT) and phase separation daily.

Functional properties determination

Bulk density, oil and water absorption capacity, swelling index specific gravity, foam stability

and dispersability were determined by the method described by Onwuka (2018). 


\section{Sensory analysis}

Sensory evaluation of the soymilk produced was carried out according to the method described by Iwe (2007). Quality attributes evaluated were taste, appearance, consistency, aroma and general acceptability. A 25 semitrained panellists from Michael Okpara University of Agriculture, Umudike Abia State, Nigeria were used to evaluate the samples using 9-point hedonic scale ranging from 9 (like extremely) to 1 (dislike extremely).

\section{Statistical Analysis}

The data obtained from this study were subjected to analysis of variance (ANOVA) using split-plot method and the mean values were determined and separated using Duncan multiple range test (SPSS 17version).

\section{Results and Discussions}

\section{Proximate Composition}

Table 1 presents the results.

Moisture Content (MC)

This is the amount of available water in the soymilk samples given as a percentage of their original weights (wet). The MC of the stabilized samples decreased significantly $(\mathrm{P}<0.05)$ from 86.39 to $84.86 \%$ with increase in OFSPS stabilization levels. The decrease could be attributed to the increase in total solids (TS) contributed by OFSPS. Besides, the plant ash used in boiling must have tenderized and aid in liquefying the soybeans more thereby increased the TS as well. Total solids had been reported to have a negative correlation with $\mathrm{MC}$ as substantiated by higher MC of control (89.09\%) than the stabilized samples (86.39 to $84.86 \%)$. However, higher MC of the entire samples established soymilk as a good easy to swallow refreshing beverage with short ambient storage stability if not properly processed, stabilized, packaged and preserved.

\section{Ash}

The ash content of the stabilized soymilk samples increased $(0.84$ to $0.88 \%)$ significantly $(\mathrm{P}<0.05)$ with increase in OFSPS stabilization levels more than control $(0.84 \%)$. Though the ash content of the control sample and $0.5 \%$ stabilized soymilk were not significantly different, it could be that, $0.5 \%$ OFSPS stabilization level did not influence the ash content of the soymilk. Generally, higher ash content of stabilized soymilk samples than the control indicated that OFSPS may have contained some minerals and therefore the primary source of increase aside from stabilization effect. Low levels of ash content of the entire samples despite improvement by plant ash and OFSPS attested to low mineral content of soymilk (STS, 1987).

\section{Protein}

The protein content of stabilized soymilk improved (4.14 to $4.24 \%)$ significantly $(\mathrm{P}<0.05)$ with increase in OFSPS stabilization levels more than the control (4.07\%). This therefore implied that OFSPS contains proteins which contributed to stabilized soymilk protein increase. Stabilized soymilk stands a better chance of increase in such health benefits as synthesis of new cell, repair of worn out tissue and other substances require for healthy functioning and development of the body. Protein also helps to build and maintain healthy muscle mass as well as supporting tendon, ligaments and other body-tissue. It also helps to prevent spikes in blood glucose, which is especially important for preventing type 2 diabetes and balancing energy (Ajani et al., 2012).

\section{Crude Fibre}

This refers to the indigestible plant material, such as vegetables, fruits, grains, beans and legumes. Fibre has been reported to offers a variety of health benefits and is essential in reducing the risk of chronic disease such as diabetes, obesity, cardiovascular disease and diverticulitis (Ajani et al., 2012). It also lowers the concentration of lowdensity lipoprotein cholesterol in the blood, possibly by binding with bile's acids (Ishiwu and Tope, 2015). Fibre content of stabilized soymilk improved (0.31 to $0.39 \%$ ) significantly $(\mathrm{P}<0.05)$ with increase in OFSPS levels of stabilization. The improvement was significantly $(\mathrm{P}<0.05)$ higher than the control which proved OFSPS as a good fibre source. Hence, stabilizing soymilk with OFSPS could be encouraged for enriching the fibre content alongside the associated health benefits.

\section{Fat}

Fat provides energy, absorbs certain nutrients and maintain body temperature (Amankwah et al., 2009). Fat is a flavour enhancer and a good source of fat soluble vitamins. Therefore, with significant $(\mathrm{P}<0.05)$ fat improvement in all stabilized soymilk samples (3.75 to $4.19 \%$ ) with increasing levels of OFSPS, there will be improvement in health benefits, flavour and fat soluble vitamins in the stabilized soymilk than control (3.83\%) especially at higher levels. However, the fat improvement could be attributed primarily to OFSPS despite fat interaction with calcium from plant ash (Igyor et al., 2011).

Carbohydrate

Carbohydrate content of OFSPS stabilized increased (4.54 to $5.55 \%)$ significantly $(\mathrm{P}<0.05)$ more than the control $(2.09 \%)$ with increase stabilization levels. The increase could be attributed to OFSPS. The improvement is beneficial as carbohydrate is an energy substrate and could contribute to soymilk viscosity and mouth feel.

Table 1. Proximate compositions of soymilk stabilized with orange fresh potato starches $(\%)$.

\begin{tabular}{|c|c|c|c|c|c|c|}
\hline Samples & Moisture & Ash & Protein & Crude Fiber & Crude fat & Carbohydrate \\
\hline $\mathrm{SS}_{0}$ & $89.09^{b} \pm 0.98$ & $0.84^{\mathrm{e}} \pm 0.02$ & $4.07^{\mathrm{d}} \pm 0.01$ & $0.30^{\mathrm{fg}} \pm 0.00$ & $3.83^{\mathrm{ab}} \pm 0.49$ & $2.09^{\mathrm{d}} \pm 0.83$ \\
\hline $\mathrm{SS}_{0.5}$ & $86.39^{\mathrm{de}} \pm 0.16$ & $0.84^{\mathrm{e}} \pm 0.01$ & $4.14^{\mathrm{dc}} \pm 0.02$ & $0.31^{\mathrm{ef}} \pm 0.01$ & $3.75^{\mathrm{ab}} \pm 0.21$ & $4.54^{c} \pm 0.19$ \\
\hline $\mathrm{SS}_{1.0}$ & $85.48^{\mathrm{ef}} \pm 0.31$ & $0.86^{\mathrm{cde}} \pm 0.04$ & $4.16^{b c} \pm 0.00$ & $0.35^{\mathrm{cd}} \pm 0.00$ & $3.95^{\mathrm{ab}} \pm 0.16$ & $5.09^{\mathrm{ab}} \pm 0.35$ \\
\hline $\mathrm{SS}_{2.0}$ & $84.91^{\mathrm{f}} \pm 0.01$ & $0.87^{\mathrm{abcd}_{ \pm}} \pm 0.00$ & $4.17^{\mathrm{b}} \pm 0.01$ & $0.36^{c} \pm 0.00$ & $4.12^{\mathrm{a}} \pm 0.04$ & $5.45^{\mathrm{ab}} \pm 0.02$ \\
\hline $\mathrm{SS}_{3.0}$ & $84.86^{f} \pm 0.06$ & $0.88^{\mathrm{ab}} \pm 0.01$ & $4.24^{\mathrm{a}} \pm 0.01$ & $0.39^{\mathrm{b}} \pm 0.00$ & $4.19^{\mathrm{a}} \pm 0.00$ & $5.55^{\mathrm{b}} \pm 0.04$ \\
\hline
\end{tabular}

Values are means of triplicate determinations \pm standard deviation. Means with the same superscripts within the same column are not significantly different $(\mathrm{P}>0.05)$. 0.5\% SS0 $=$ Un-stabilized soymilk (control), SS0.5=0.55\% stabilized soymilk, SS $1.0=1.0 \%$ stabilized soymilk, SS2.0 $=2.0 \%$ stabilized soymilk and SS3.0 $=3.0 \%$ stabilized soymilk 
Table 2. Vitamin compositions of soymilk stabilized with orange fresh sweet potato starch.

\begin{tabular}{l|ccccc}
\hline \multicolumn{1}{c|}{ Samples } & $\begin{array}{c}\text { Vitamin } \mathrm{B}_{1} \\
(\mathrm{mg} / 100 \mathrm{~g})\end{array}$ & $\begin{array}{c}\text { Vitamin } \mathrm{B}_{2} \\
(\mathrm{mg} / 100 \mathrm{~g})\end{array}$ & $\begin{array}{c}\text { Vitamin } \mathrm{B}_{3} \\
(\mathrm{mg} / 100 \mathrm{~g})\end{array}$ & $\begin{array}{c}\text { Vitamin C } \\
(\mathrm{mg} / 100 \mathrm{~g})\end{array}$ & $\begin{array}{c}\text { Pro-vitamin A } \\
(\mu \mathrm{g} / 100 \mathrm{~g})\end{array}$ \\
\hline $\mathrm{SS}_{0}$ & $0.25^{\mathrm{ef}_{0}} \pm 0.01$ & $0.09^{\mathrm{cde}_{0}} \pm 0.00$ & $0.90^{\mathrm{d}} \pm 0.01$ & $0.85^{\mathrm{d}} \pm 0.01$ & $4.62^{\mathrm{e}} \pm 0.00$ \\
$\mathrm{SS}_{0.5}$ & $0.29^{\mathrm{d}} \pm 0.01$ & $0.10^{\mathrm{cde}_{0}} \pm 0.00$ & $1.03^{\mathrm{c}} \pm 0.01$ & $0.86^{\mathrm{d}} \pm 0.01$ & $5.75^{\mathrm{d}} \pm 0.01$ \\
$\mathrm{SS}_{1.0}$ & $0.32^{\mathrm{c}} \pm 0.00$ & $0.11^{\mathrm{bcd}} \pm 0.00$ & $1.06^{\mathrm{b}} \pm 0.01$ & $1.03^{\mathrm{b}} \pm 0.01$ & $5.86^{\mathrm{c}} \pm 0.02$ \\
$\mathrm{SS}_{2.0}$ & $0.36^{\mathrm{b}} \pm 0.01$ & $0.12^{\mathrm{b}} \pm 0.00$ & $1.08^{\mathrm{b}} \pm 0.00$ & $1.04^{\mathrm{b}} \pm 0.01$ & $5.91^{\mathrm{b}} \pm 0.01$ \\
$\mathrm{SS}_{3.0}$ & $0.40^{\mathrm{a}} \pm 0.03$ & $0.14^{\mathrm{a}} \pm 0.01$ & $1.13^{\mathrm{a}} \pm 0.01$ & $1.09^{\mathrm{a}} \pm 0.01$ & $6.14^{\mathrm{a}} \pm 0.03$ \\
\hline
\end{tabular}

Values are means of triplicate determinations \pm standard deviation. Values with the same superscripts within the same column are not significantly different $(\mathrm{P}>0.05)$. $\mathrm{SS}_{0}$-un-stabilized soymilk (control), $\mathrm{SS}_{0.5}-0.5 \%$ stabilized soymilk, $\mathrm{SS}_{1.0}-1.0 \%$ stabilized soymilk, $\mathrm{SS}_{2.0}-2.0 \%$ stabilized soymilk and $\mathrm{SS}_{3.0}-3.0 \%$ stabilized soymilk

Table 3. Mineral composition of stabilized soymilk samples (mg/100g).

\begin{tabular}{l|ccccc}
\hline \multicolumn{1}{c|}{ Samples } & Calcium & Potassium & Magnesium & Sodium & Iron \\
\hline $\mathrm{SS}_{0}$ & $27.74^{\mathrm{b}} \pm 0.08$ & $30.31^{\mathrm{d}} \pm 0.02$ & $44.54^{\mathrm{b}} \pm 0.34$ & $31.76^{\mathrm{f}} \pm 0.06$ & $2.74^{\mathrm{g}} \pm 0.03$ \\
$\mathrm{SS}_{0.5}$ & $26.81^{\mathrm{c}} \pm 0.13$ & $31.54^{\mathrm{bc}} \pm 0.08$ & $44.40^{\mathrm{b}} \pm 0.14$ & $32.73^{\mathrm{d}} \pm 0.11$ & $2.82^{\mathrm{f}} \pm 0.02$ \\
$\mathrm{SS}_{1.0}$ & $27.13^{\mathrm{b}} \pm 0.39$ & $32.60^{\mathrm{a}} \pm 0.28$ & $46.26^{\mathrm{a}} \pm 0.77$ & $32.83^{\mathrm{d}} \pm 0.04$ & $3.22^{\mathrm{d}} \pm 0.05$ \\
$\mathrm{SS}_{2.0}$ & $27.53^{\mathrm{b}} \pm 0.11$ & $32.69^{\mathrm{a}} \pm 0.01$ & $46.28^{\mathrm{a}} \pm 0.04$ & $32.86^{\mathrm{d}} \pm 0.08$ & $3.37^{\mathrm{c}} \pm 0.04$ \\
$\mathrm{SS}_{3.0}$ & $28.55^{\mathrm{a}} \pm 0.07$ & $32.95^{\mathrm{a}} \pm 0.64$ & $46.82^{\mathrm{a}} \pm 0.05$ & $33.43^{\mathrm{a}} \pm 0.04$ & $3.71^{\mathrm{a}} \pm 0.01$ \\
\hline
\end{tabular}

\section{Vitamin Composition}

The results are presented in Table 2

\section{Vitamin $B_{1}$ (Thiamin)}

Thiamin content of OFSPS stabilized soymilk samples improved $(0.29$ to $0.4 \mathrm{mg} / 100 \mathrm{~g})$ significantly $(\mathrm{P}<0.05)$ more than control sample $(0.25 \mathrm{mg} / 100 \mathrm{~g})$. The OFSPS could be the primary source of increase which substantiated the report of Berski et al. (2011) that OFSPS is a good source of vitamin. The values are reasonable despite inevitable processing loss.

\section{Vitamin $B_{2}$ (Riboflavin)}

Riboflavin content of OFSPS stabilized soymilk samples improved $(0.10-0.14 \mathrm{mg} / 100 \mathrm{~g})$ significantly $(\mathrm{P}<0.05)$ as stabilization levels increases more than control sample $(0.09 \mathrm{mg} / 100 \mathrm{~g})$. The improvement is very much desired as riboflavin plays a supportive role in the treatment of sickle-cell anaemia (Knapp, 2011). Its appreciable presence in food could contribute towards keeping healthy blood cells. General low $\mathrm{B}_{2}$ values may be due to processing losses.

\section{Vitamin $B_{3}$ (Niacin)}

The OFSPS stabilization of soymilk samples improved the niacin (1.03 to $1.13 \mathrm{mg} / 100 \mathrm{~g})$ higher than the control sample $(0.90 \mathrm{mg} / 100 \mathrm{~g})$. The OFSPS must have been the primary contributor which is a welcomed development as thiamine is precursor for enzyme co-factors that work as catalyst in body metabolism. Niacin deficiency results in pellagra (Duel and Sturtz, 2010).

\section{Vitamin $C$}

This is a very important antioxidant, required for proper development and health of man (Knapp, 2011). Significant amount of vitamin $\mathrm{C}$ in foods prevents free radical formation, stabilizes food nutrients, aids in detoxifying alcohol and other harmful substance as well as protects people from diabetes (Raff et al., 2004). Increase in OFSPS stabilization improved the vitamin $\mathrm{C}$ content ( 0.86 to 1.09 $\mathrm{mg} / 100 \mathrm{~g})$ significantly $(\mathrm{P}<0.05)$ more than the control $(0.85 \mathrm{mg} / 100 \mathrm{~g})$ which will in turn improve the health benefits. The improvement justified the claim that OFSPS is a good source. Low vitamin C content of the control sample could be attributed to inevitable processing loss as vitamin $\mathrm{C}$ is heat labile.

\section{Pro-vitamin A (Retinol)}

Like all other vitamins, retinol content of stabilized soymilk increased (5.75 to $6.14 \mu \mathrm{g} / 100 \mathrm{~g}$ ) significantly $(\mathrm{P}<0.05)$ with OFSPS stabilization levels. Significant $(\mathrm{P}<0.05)$ higher retinol content of the stabilized soymilk than the control $(4.62 \mu \mathrm{g} / 100 \mathrm{~g})$ substantiated the report of Bulean et al. (2008) that OFSP is a good vitamin A source and therefore the main source of increase. The retinol improvement is very much desired as it is responsible for vision and maintenance of epithelial cell functions (Akuyili et al., 2013). Higher retinol values projected stabilized soymilk samples as good sources. Vitamin A is an essential fat-soluble vitamin whose functions include; growth maintenance, good vision, maintaining the structure and function of the skin cell and mucous membranes (Ihekoronye and Ngoddy, 1985).

\section{Mineral Composition}

The results are shown in Table 3.

\section{Calcium}

Calcium content of OFSPS stabilized samples was significantly $(\mathrm{P}<0.05)$ enhanced $(26.81$ to $28.55 \mathrm{mg} / 100 \mathrm{~g})$ with increase in stabilization levels more than the control sample $(27.74 \mathrm{mg} / 100 \mathrm{~g})$. Higher calcium content of control sample than that from $0.5 \%$ OFSPS stabilized soymilk could suggest low calcium content liable to make reasonable impart as from $1 \%$ probably due to calcium and protein interactions. At $0.5 \%$ stabilization level, more available protein (Table 1) will interact with little calcium from that level. Same reason may explain the reason for non-significant $(\mathrm{P}>0.05)$ variation between samples $\mathrm{SS}_{1.0}$ and $\mathrm{SS}_{2.0}$ stabilized respectively with 1 and $2 \%$ OFSPS. Calcium content of the samples was quite appreciable probably due to plant ash and OFSPS as major sources. Calcium enhancement is desired as it helps in the building and maintenance of teeth and it plays a key role in our cells (Okwunodulu et al., 2018).

Values are means of triplicate determinations \pm standard deviation. Means with the same superscripts within the same column are not significantly $(\mathrm{P}>0.05)$ different. $\mathrm{SS}_{0}$-un-stabilized soymilk (control), $\mathrm{SS}_{0.5}$ $0.5 \%$ stabilized soymilk, $\mathrm{SS}_{1.0}-1.0 \%$ stabilized soymilk, $\mathrm{SS}_{2.0}-2.0 \%$ stabilized soymilk and $\mathrm{SS}_{3.0}-$ $3.0 \%$ stabilized soymilk. 


\section{Potassium}

Potassium content of stabilized soymilk improved ( 31.54 to $32.95 \mathrm{mg} / 100 \mathrm{~g})$ significantly $(\mathrm{P}<0.05)$ more than control $(30.31 \mathrm{mg} / 100 \mathrm{~g})$ with increase in OFSPS stabilization levels only at $0.5 \%$. The OFSPS could be the source of increment aside from plant ash (Okwunodulu et al., 2018). Amidst the increment, there was no significant contribution from OFSPS stabilization at levels 1, 2 and 3 $\%$ which predisposed OFSPS poor potassium source. Potassium improvement is encouraged as it will contribute meaningfully to the recommended daily requirement and proper functioning of all cells, tissues, and organs in the human body. Potassium along with sodium, calcium and magnesium is an electrolyte which conducts electricity in the body. It plays a key role in skeletal and smooth muscle contraction, making it important for normal digestive and muscular function (Gerlin et al., 2007).

\section{Magnesium}

This is a cofactor in more than 300 enzyme systems that regulate diverse biochemical reactions in the body including protein synthesis, muscle and nerve function, blood glucose control, and blood pressure regulation (Aydin et al., 2010). It contributes to the structural development of bone and is required for the synthesis of DNA, RNA and antioxidant glutathione. Magnesium content of the stabilized soymilk improved (44.40 to 46.82 $\mathrm{mg} / 100 \mathrm{~g})$ significantly $(\mathrm{P}<0.05)$ only as from $1 \%$ stabilization level as the control and $0.5 \%$ stabilized sample did not differ. The improvement was higher than the control (44.54 mg/100g) which points to OFSPS as a poor magnesium source which made significant $(\mathrm{P}<0.05)$ contribution only as from $1 \%$ level. The improvement is desired as it will enhance the health benefits.

\section{Sodium}

The sodium content of the stabilized soymilk samples (32.73 to $33.43 \mathrm{mg} / 100 \mathrm{~g})$ were significantly $(\mathrm{P}<0.05)$ enhanced more than control (31.76 mg/100g) with increasing level of OFSPS stabilization. The enhancement was only significant at 3\% level as $0.5,1$ and $2 \%$ OFSPS stabilized soymilk were not different. May be OFSPS is not a good source of sodium which is beneficial as high sodium is associated with high blood pressure (Onwuka, 2018). Low sodium prevention of high blood pressure, aids in the functioning of the nervous system, muscular contractions and nerve sending signals conducted through movement of positively charged sodium particles. They also help to maintain fluid balance in the body (Gomez-Candela et al., 2011).

Iron

Iron content was significantly $(\mathrm{P}<0.05)$ higher in the stabilized soymilk samples (2.82 to $3.71 \mathrm{mg} / 100 \mathrm{~g}$ ) than in control $(2.74 \mathrm{mg} / 100 \mathrm{~g})$ due to OFSPS stabilization. The, iron content increased with increased OFSPS stabilization levels. Iron works in synergy with protein and copper to produce red blood cells that transport oxygen from lungs to all the tissues for growth (Fallon and Enig, 2007). The increment is creditable because of its numerous endowed health benefits. Iron helps our muscles to store and use oxygen, and also part of many other proteins and enzymes (Wessling-Resnick, 2014). High iron content of all stabilized samples in this study projected them as good iron source.

\section{Anti-Nutrient Composition}

The results are presented in Table 4.

Saponins are steroid or triterpenoid aglycone containing compounds linked to one or more oligosaccharide which absorption and effects are restricted to the intestinal tract ( $\mathrm{Li}$ et al., 2010). They reduce digestion and bioavailability of proteins by inhibiting or decreasing various digestive enzymes such as trypsin and chymotrypsin (Liener, 2003). Also, saponin can form complexes with zinc and iron, thus, limiting their bioavailability (Sun et al., 2009). Saponin content of the stabilized samples $(0.028$ to $0.035 \mathrm{mg} / 100 \mathrm{~g})$ increased significantly $(\mathrm{P}<0.05)$ more than the control $(0.025$ $\mathrm{mg} / 100 \mathrm{~g}$ ) with increase in OFSPS stabilization levels. The OFSPS may have contained minimal level of soponin. Fortunately, the increment was lower than stipulated safe limit of 5 to $10 \mathrm{mg} / \mathrm{kg}$ food (Ndie and Okaka, 2018). Therefore, OFSPS stabilized soymilk samples are safe for human consumption.

Table 4. Effect of stabilization on the phytochemical compositions of soymilk samples (mg/100g).

\begin{tabular}{l|ccccc}
\hline \multicolumn{1}{c|}{ Samples } & Saponin & Tannin & Flavonoid & Alkaloids & Phenols \\
\hline $\mathrm{SS}_{\mathrm{o}}$ & $0.025^{\mathrm{d}} \pm 0.98$ & $0.041^{\mathrm{cd}} \pm 0.00$ & $0.028^{\mathrm{e}} \pm 0.00$ & $0.024^{\mathrm{d}} \pm 0.01$ & $0.022^{\mathrm{e}} \pm 0.00$ \\
$\mathrm{SS}_{0.5}$ & $0.028^{\mathrm{c}} \pm 0.16$ & $0.041^{\mathrm{d}} \pm 0.00$ & $0.031^{\mathrm{b}} \pm 0.00$ & $0.025^{\mathrm{cd}} \pm 0.00$ & $0.025^{\mathrm{d}} \pm 0.00$ \\
$\mathrm{SS}_{1.0}$ & $0.031^{\mathrm{bc}_{1}} \pm 0.31$ & $0.045^{\mathrm{b}} \pm 0.00$ & $0.030^{\mathrm{b}} \pm 0.00$ & $0.028^{\mathrm{c}} \pm 0.00$ & $0.028^{\mathrm{c}} \pm 0.00$ \\
$\mathrm{SS}_{2.0}$ & $0.033^{\mathrm{ab}} \pm 0.13$ & $0.046^{\mathrm{b}} \pm 0.00$ & $0.034^{\mathrm{a}} \pm 0.00$ & $0.031^{\mathrm{b}} \pm 0.00$ & $0.031^{\mathrm{b}} \pm 0.00$ \\
$\mathrm{SS}_{3.0}$ & $0.035^{\mathrm{a}} \pm 0.01$ & $0.048^{\mathrm{a}} \pm 0.00$ & $0.034^{\mathrm{a}} \pm 0.00$ & $0.034^{\mathrm{a}} \pm 0.00$ & $0.034^{\mathrm{a}} \pm 0.00$ \\
\hline
\end{tabular}

Values are means of triplicate determinations \pm standard deviation. Means with the same superscripts within the same column are not significantly $(\mathrm{P}>0.05)$ different. $\mathrm{SS}_{0}$ un-stabilized soymilk (control), $\mathrm{SS}_{0.5}-0.5 \%$ stabilized soymilk, $\mathrm{SS}_{1.0}-1.0 \%$ stabilized soymilk, $\mathrm{SS}_{2.0}-2.0 \%$ stabilized soymilk and $\mathrm{SS}_{3.0}-3.0 \%$ stabilized soymilk.

\section{Tannin}

Tannin content of stabilized soymilk samples $(0.041$ to $0.048 \mathrm{mg} / 100 \mathrm{~g})$ were significantly $(\mathrm{P}<0.05)$ increased more than control $(0.041 \mathrm{mg} / 100 \mathrm{~g})$ with increase in OFSPS stabilization levels. Therefore, OFSPS may have contained some traces of tannin which contributed to tannin increase. Tannin is heat stable, astringent and bitter plant polyphenolic compound that inhibits bioavailability of proteins and various other organic compounds like amino acids and alkaloids (Ijeh et al., 2010). Tannin decreases their digestibility by inhibiting digestive enzymes (trypsin, chemotrypsin, amylase and lipase) and increasing fecal nitrogen (Ferrell and Thorington, 2006). Tannin content of all the soymilk samples were considerably lower than stipulated safe limit of $120 \mathrm{mg} / \mathrm{kg}$ food (Ndie and Okaka, 2018) and would have minimal interference on intestinal digestion, enzyme activities and iron absorption.

\section{Flavonoid}

The flavonoid content of the stabilized samples increased significantly $(\mathrm{P}<0.05)$ from 0.031 to 0.034 
$\mathrm{mg} / 100 \mathrm{~g}$ than the control $(0.028 \mathrm{mg} / 100 \mathrm{~g})$ with increase in OFSPS stabilization levels. The difference was significant $(\mathrm{P}<0.05)$ only as from $1 \%$ level indicating that flavonoid content of OFSPS may be low with only influence at relatively higher levels. Despite the increase, the flavonoid concentrations were generally low and may have no adverse health effects.

Alkaloid

Alkaloid content of stabilized soymilk samples also increased $(0.025$ to $0.034 \mathrm{mg} / 100 \mathrm{~g})$ significantly $(\mathrm{P}<0.05)$ more than control $(0.024 \mathrm{mg} / 100 \mathrm{~g})$ with increase in OFSPS stabilization levels. However, the values obtained in this study are considerably low which may likely have little or no adverse health effect.

Phenol

Significant $(\mathrm{P}<0.05)$ increase and phenol content levels of the stabilized soymilk samples $(0.025$ to $0.034 \mathrm{mg} / 100 \mathrm{~g})$ more than the control sample $(0.022 \mathrm{mg} / 100 \mathrm{~g})$ indicated that OFSPS contained minimal level of phenol without adverse health effects. Therefore, stabilized soymilk is safe for human consumption since the levels were within stipulated safe limit.

\section{Physicochemical Properties}

The results are shown in Table 5.

Viscosity

Stabilization of soymilk samples with OFSPS increased the viscosity significantly $(\mathrm{P}<0.05)$ from 4.89 to $5.60 \mathrm{cp}$ with increase in stabilization levels) more than control $(4.74 \mathrm{cp})$. The increase points to OFSPS as the primarily source and therefore has a good stabilizing capability. Viscosity is the measure of acceptability and stability, the more viscous the soymilk, the less acceptability and stability. Also less viscous soymilk is more likely to undergo separation and sedimentation which will also result in poor acceptability and ambient storage stability. Therefore, a balance between the two will be most preferred.

Table 5. Effects of stabilization on the physicochemical properties of soymilk.

\begin{tabular}{llllll} 
Samples & Viscosity $(c p)$ & $p H$ & Specific gravity & VCT $(\mathrm{d})$ & Foam stability $(\mathrm{s})$ \\
\hline $\mathrm{SS}_{\mathrm{O}}$ & $4.74^{\mathrm{d}} \pm 0.01$ & $5.77^{\mathrm{a}} \pm 0.01$ & $1.02^{\mathrm{ab}} \pm 0.00$ & $20.00^{\mathrm{e}} \pm 0.70$ & $0.00^{\mathrm{d}} \pm 0.00$ \\
$\mathrm{SS}_{0.5}$ & $4.89^{\mathrm{c}} \pm 0.01$ & $5.75^{\mathrm{b}} \pm 0.01$ & $1.02^{\mathrm{ab}} \pm 0.00$ & $28.00^{\mathrm{a}} \pm 0.70$ & $0.51^{\mathrm{c}} \pm 0.01$ \\
$\mathrm{SS}_{1.0}$ & $5.25^{\mathrm{bc}} \pm 0.01$ & $5.72^{\mathrm{c}} \pm 0.01$ & $1.03^{\mathrm{a}} \pm 0.00$ & $18.00^{\mathrm{g}} \pm 0.00$ & $0.00^{\mathrm{d}} \pm 0.00$ \\
$\mathrm{SS}_{2.0}$ & $5.31^{\mathrm{b}} \pm 0.70$ & $5.60^{\mathrm{d}} \pm 0.01$ & $1.04^{\mathrm{a}} \pm 0.00$ & $15.00^{\mathrm{h}} \pm 0.00$ & $0.00^{\mathrm{d}} \pm 0.00$ \\
$\mathrm{SS}_{3.0}$ & $5.60^{\mathrm{a}} \pm 0.01$ & $5.45^{\mathrm{h}} \pm 0.00$ & $1.04^{\mathrm{a}} \pm 0.00$ & $14.00^{\mathrm{h}} \pm 0.00$ & $0.00^{\mathrm{d}} \pm 0.00$ \\
\hline
\end{tabular}

Values are means of triplicate determinations \pm standard deviation. Means with the same superscripts within the same column are not significantly (P>0.05) different. $\mathrm{SS}_{0}$-un-stabilized soymilk (control), $\mathrm{SS}_{0.5}-0.5 \%$ stabilized soymilk, $\mathrm{SS}_{1.0}-1.0 \%$ stabilized soymilk, $\mathrm{SS}_{2.0}-2.0 \%$ stabilized soymilk and $\mathrm{SS}_{3.0}-3.0 \%$ stabilized soymilk.

\section{$p H$}

There was significant $(\mathrm{P}<0.05) \mathrm{pH}$ decrease of stabilized soymilk samples (5.75 to 5.45 ) less than the control sample (5.77) with increase in OFSPS stabilization levels. The increase which solely came from OFSPS could be attributed to some of its edible acids content like ascorbic acid (Table 2) which decreased the $\mathrm{pH}$ despite the increase by plant ash. The significant $\mathrm{pH}$ reduction by OFSPS signified acidity increase which may likely favour interaction and sedimentation (Okwunodulu et al., 2017b) over time thereby reduce acceptability and storage stability. Level of OFSPS stabilization should therefore not be more than $1 \%$ in this regard.

Specific gravity $(S G)$

The SG of the stabilized soymilk samples increased (1.02 to 1.04$)$ significantly $(\mathrm{P}<0.05)$ more than the control sample (1.02) as from 1\% level of OFSPS stabilization. This may indicate that OFSPS had low SG liable to make significant $(\mathrm{P}<0.05)$ variation at higher level as obtained in this study. Low SG in this study signified desirable consistency which will enhance mouth feel, acceptability and visible coagulation time (stability).

Visible coagulation time (VCT)

This is the time (days) taken for visible coagulation and separation to occur and it is a measure of product ambient storage stability. The VCT of the stabilized soymilk samples decreased $(28$ to $14 \mathrm{~d})$ significantly $(\mathrm{P}<0.05)$ less than control $(20 \mathrm{~d})$ as the OFSPS stabilization levels increased. The decrease could be ascribed to the increasing acidity with increasing stabilization levels. Acidity increase lowers the VCT (Okwunodulu et al., 2017b) hence, the higher VCT at $0.5 \%$ (28 d) than the other levels. However, beyond $0.5 \%$, the VCT was lower than the control which is an economic waste.

\section{Foam stability (FS)}

This refers to the ability of protein to stabilize against the gravitational and mechanical stress. The FS of the stabilized soymilk samples was maximum $(0.51)$ at $0.5 \%$ level of OFSPS stabilization unlike the other levels with 0.00 FS including the control sample. Zero FS obtained in this study except in sample $\mathrm{SS}_{0.5}(0.5 \%$ stabilized soymilk) could signify low OFSPS protein content which also was disintegrated during milling. As protein plays an important role in foam network formation, the higher the stabilization level, the more the carbohydrate than protein and the lower the FS with this, it becomes evident that only at lower level $(0.5 \%)$ of OFSPS soymilk stabilization that maximum FS could be achieved. The FS is a measure of freshness and soymilk stability which is optimal at $0.5 \%$ level of stabilization beyond which it is not economical.

\section{Functional Composition}

The results are presented in Table 6.

Bulk density $(B D)$

Density is defined as the mass per unit volume of a substance which reveals the porosity and weight of a food material thereby making it a criteria for choice of packaging materials (Onimawo and Akurbor, 2005). The BD of OFSPS $(0.63 \mathrm{~g} / \mathrm{ml})$ is lower than 0.92 to $0.97 \mathrm{~g} / \mathrm{ml})$ reported by Okoye et al. (2007) from corn starch/soybean flour blends and the values $(0.94$ to $0.98 \mathrm{~g} / \mathrm{ml})$ reported by Okoye et al. (2017) for sorghum/African yam bean blends. Low BD of OFSPS is advantageous for stabilizing soymilk to avoid coagulation and loss of desirable consistency (Amandikwa, 2012). 


\section{Solubility}

Low solubility value $(13.68 \%)$ of OFSPS could result from low amylase content (Berski et al., 2011; Wikipedia, 2019) which is not encouraging as the OFSPS must dissolve to effect stabilization. The low value could be attributed to the source and processing technique and may be enhanced during soymilk sterilization. The more soluble the starch granules, the higher the medium viscosity, the more the soymilk solids are evenly dispersed and suspended, and the better the ambient stability (Okwunodulu and Abasiekong, 2015).

Swelling index (SI)

This measures how much water a food material can absorb depending on carbohydrate content. Low SI of OFSPS $(3.76 \%)$ which could be attached to low WAC and components (Boye et al., 2011) may be improved by the processing heat. Higher values may bind most of the soymilk free water thereby increase the viscosity beyond desirable limit, reduce acceptability, refreshing value and loss of stabilization value.

\section{Dispersibility}

This is the ability of the starch granules to disperse evenly within the food matrix. The more they are evenly disperse, the lower the interaction, separation and sedimentation, the more stable the soymilk. High dispersibility value of OFSPS $(85.36 \%)$ will improve the soymilk mouth feel, acceptability and ambient storage.

Least gelation capacity

This is the least protein concentration required by food to form self supporting gel. The OFSPS with a value of
10.00 is an indication of a good gelling capacity (Onimawo and Egbekun, 1998) which signifies better consistency, mouth feel and acceptability of OFSPS stabilized soymilk.

Water Absorption Capacity (WAC)

This is a hydration property of the OFSPS that refers to the amount of water absorbed per gram depending on particle sizes (Boye et al., 2011). It correlates inversely with MC (Hoover, 2001). Low WAC of OFSPS (2.79 g/g) could stem from destruction of the macromolecular matrix that entraps large amount of water during processing (Chen and Lin, 2002). The low WAC also will enhance soymilk consistency and ambient storage stability.

\section{Oil absorption capacity (OAC)}

This is the ability of food material to absorb oil which helps to improve the mouth feel and retains flavour (Egan et al., 1981). Low OAC (2.31 g/g) of OFSPS signified low absorption of oil content of soymilk samples by OFSPS in stabilized soymilk samples. Soymilk oil helps to boost energy, mouth fell and flavour of soymilk.

\section{Sensory Characteristics}

The scores are presented in table 7.

Taste

Taste scores of the stabilized soymilk samples decreased with increasing levels of OFSPS. Sample $\mathrm{SS}_{0.5}$ (0.5 stabilized soymilk) had the highest score (6.84) which is significantly $(\mathrm{P}<0.05)$ higher than the control sample (6.72). Sample $\mathrm{SS}_{3.0}$ (3\% stabilized soymilk) had the lowest rating (4.44).

Table 6. Functional properties of orange flesh sweet potato starch flour

\begin{tabular}{l|ccccccc}
\hline \multirow{2}{*}{ Sample } & $\begin{array}{c}\text { B D } \\
(\mathrm{g} / \mathrm{ml})\end{array}$ & $\begin{array}{c}\text { Solubility } \\
(\%)\end{array}$ & $\begin{array}{c}\text { S I } \\
(\%)\end{array}$ & $\begin{array}{c}\text { Dispersibility } \\
(\%)\end{array}$ & $\begin{array}{c}\text { LGC } \\
\text { Wt }(\mathrm{v} / \mathrm{v} .)\end{array}$ & $\begin{array}{c}\text { WAC } \\
(\mathrm{g} / \mathrm{g})\end{array}$ & $\begin{array}{c}\text { OAC } \\
(\mathrm{g} / \mathrm{g})\end{array}$ \\
\hline OFSP & $0.63 \pm 0.00$ & $13.68 \pm 0.04$ & $3.76 \pm 0.08$ & $85.36 \pm 0.08$ & $10.00 \pm 0.00$ & $2.79 \pm 0.01$ & $2.31 \pm 0.01$ \\
\hline
\end{tabular}

Values are means of triplicate determinations \pm standard deviation. Means with the same superscripts within the same column are not significantly $(\mathrm{P}>0.05)$ different. BD- bulk density, SI-swelling index, LGC - least gelatinization capacity, WAC- water absorption capacity, OAC- oil absorption capacity and OFSP- Orange flesh sweet potato.

Table 7. Effects of orange fresh potato starch stabilization on the sensory characteristics of the soymilk.

\begin{tabular}{l|ccccc}
\hline Samples & Taste & Appearance & Consistency & Aroma & Acceptability \\
\hline $\mathrm{SS}_{0}$ & $6.72^{\mathrm{ab}} \pm 1.67$ & $7.40^{\mathrm{a}} \pm 1.71$ & $7.16^{\mathrm{a}} \pm 1.25$ & $6.88^{\mathrm{a}} \pm 1.62$ & $6.92^{\mathrm{a}} \pm 1.58$ \\
$\mathrm{SS}_{0.5}$ & $6.84^{\mathrm{a}} \pm 1.41$ & $7.16^{\mathrm{ab}} \pm 1.52$ & $7.32^{\mathrm{a}} \pm 1.46$ & $6.72^{\mathrm{a}} \pm 1.90$ & $6.80^{\mathrm{a}} \pm 1.66$ \\
$\mathrm{SS}_{1.0}$ & $5.88^{\mathrm{b}} \pm 1.72$ & $7.60^{\mathrm{a}} \pm 1.29$ & $7.24^{\mathrm{a}} \pm 1.51$ & $6.56^{\mathrm{a}} \pm 1.76$ & $6.84^{\mathrm{a}} \pm 1.07$ \\
$\mathrm{SS}_{2.0}$ & $6.12^{\mathrm{ab}} \pm 1.76$ & $7.16^{\mathrm{a}} \pm 1.49$ & $5.92^{\mathrm{b}} \pm 2.20$ & $5.24^{\mathrm{b}} \pm 2.28$ & $6.36^{\mathrm{b}} \pm 0.91$ \\
$\mathrm{SS}_{3.0}$ & $4.44^{\mathrm{c}} \pm 2.10$ & $6.24^{\mathrm{b}} \pm 2.15$ & $4.44^{\mathrm{c}} \pm 2.02$ & $4.48^{\mathrm{c}} \pm 1.53$ & $4.84^{\mathrm{c}} \pm 1.91$ \\
\hline
\end{tabular}

Values are means of triplicate determinations \pm standard deviation. Means with the same superscripts within the same column are not significantly $(\mathrm{P}>0.05)$ different. $\mathrm{SS}_{0}$ un-stabilized soymilk (control), $\mathrm{SS}_{0.5}-0.5 \%$ stabilized soymilk, $\mathrm{SS}_{1.0}-1.0 \%$ stabilized soymilk, $\mathrm{SS}_{2.0}-2.0 \%$ stabilized soymilk and $\mathrm{SS}_{3.0}-3.0 \%$ stabilized soymilk.

\section{Appearance}

Appearance decreased (7.60 to 6.24) as OFSPS stabilization levels increased with sample $\mathrm{SS}_{1.0}(1.0 \%$ stabilized soymilk) having the highest score (7.60) which varied significantly from the control (7.40). Therefore, $1 \%$ stabilization had the best soymilk appearance.

Consistency

Consistency of stabilized soymilk samples which decreased with increase in stabilization levels had significant $(\mathrm{P}<0.05)$ variations as $2 \%$ stabilization. Samples $\mathrm{SS}_{0}, \mathrm{SS}_{0.5}$ and $\mathrm{SS}_{1.0}$ with respective stabilization levels of $0,0.5$ and $1 \%$ which had no difference were scored highest. Maximum of $1 \%$ stabilization will give the best consistency.

Aroma

Stabilized soymilk (6.72 to 6.56) aroma was significant $(\mathrm{P}<0.05)$ as from $2 \%$ stabilization level showing that stabilization beyond $2 \%$ will decrease the aroma. There were no significant aroma variation between 0.5 and $1 \%$ stabilized soymilk and control.

General acceptability

The 0.5 and $1 \%$ levels of OFSPS soymilk stabilization (6.80 to 6.84$)$ had no significant $(\mathrm{P}<0.05)$ acceptability variation with the control sample (6.92). Therefore, 
soymilk stabilization with OFSPS up to $1 \%$ is acceptable at the level of liked moderately.

\section{Conclusion}

This study revealed that with increase in soymilk stabilization levels ( 0.5 to $3 \%)$ with orange flesh sweet potato starch, proximate, vitamin and mineral compositions were improved. Though the values of antinutrients increased, their levels were lower than the stipulated safe limit thereby projected the stabilized soymilk safe for human consumption. Physical analysis revealed that maximum stabilization level of $1 \%$ desirably increased viscosity, specific gravity while $\mathrm{pH}$, visible coagulation time and foam stability decreased. All the functional properties were improved despite low solubility value which can be enhanced during soymilk sterilization. Sensory properties also showed that soymilk stabilization with orange flesh potato starch was moderately accepted at not more than $1 \%$ level else, it may be rejected.

\section{Acknowledgement}

The authors are grateful to the Department of Food Science and Technology, Michael Okpara University of Agriculture Umudike Abia State, Nigeria for providing the reagents and space for the analysis.

\section{References}

Achouri A, Boye JI, Zamani Y. 2007. Changes in soy milk quality as a function of composition and storage. Journal of food quality, 30: 731- 744 .

Agrahar MD, Jha K. 2014. Effect of sprouting on nutritional ad functional characteristics of soybean (Glycine max). Journal of Food Science and Technology, 46 (3): 240 -243.

Ajani AO, Oshundahunsi OF, Akinoso R, Arowora KA, Abiodun AA, Pessu PO. 2012. Proximate composition and sensory qualities of snacks produced from breadfruit flour. Global Journal of Science Frontier Research Biological Sciences. 12 (7): 2249-4626. Version 1.0. Online ISSN

Akuyili DO, Igwe SA, Ogbogu CE. 2013. Effects of garden egg on some visual functions of visually active Igbos of Nigeria. Journal of Ethnopharmacology, 4: 25-40.

Amandikwa C. 2012. Proximate and functional properties of open air solar and oven dried cocoyam flour. International Journal of Agriculture and Rural Development, 15(2): 988-994.

Amankwah EA, Barimah J, Nuamah AKM, Oldham JH, Nnaji CO. 2009. Formulation of weaning food from fermented Maize, Rice, Soybean, and fish meal. Pakistan Journal of nutrition, 8 (11): 1747 - 1752 .

AOAC. 2010. Association of Official Analytical Chemists, Official Methods of Analysis $18^{\text {th }}$ Edition Washington, D.C., USA.

Aydin S, Croteau G, Sahin I, Citil C. 2010. Ghrelin, nitrite and paraoxonase/ arylesterase concentrations in cement plant worker. Journal of medical Biochemistry, 29 (2): 78-83.

Berski W, Ptaszek A, Ptaszek P, Ziobro R, Kowalski G, Grzesik, M, Achremowicz B. 2011. Pasting and rheological properties of oat starch and its derivatives. Carbohydrate polymers, 83 (2): $665-671$.

Boye JI, Zubair F. 2011. Water holding capacity In: Pulse Foods http://www.sciencedirect.com/topic/agricultural and biological sciences/water-binding/pdf

Bulean A, Colonna P, Planchot V, Ball S. 2008. Starch granules, structure and biosynthesis. International Journal of Biological Macromolecules, 23 (2): 85 - 112.
Chen LA, Lin CS. 2002. Sensory characteristics of sorghum composite bread. International Journal Food Science Technology, 35: $465-471$.

Duel F, Sturtz C. 2010. Biochemistry of fruits and their products. $2^{\text {nd }}$ ed. London: Acatlenic Press, Pp 80-81.

Egan H, Kirk R S, Sawyer R. 1981. Pearson's chemical analysis of foods, $8^{\text {th }}$ edi. UKL: Essexi Longman Scientific and Technical.

Eke- Ejiofor J. 2015. Physicochemical and pasting properties of starches from cassava, sweet potato and three (3) yam and their application in salad cream production. International Journal of Biotechnology and Food Science, 3 (2): 23-30.

Fallon S, Enig MG. 2007. Nourishing Tradition In: The Cookbook that Challenges Politically Correct Nutrition and the Diet Dictocrates.NewTrends Publishing Inc.www. Newtrendpublishing.com.

Ferrell KE, Thorington RW. 2006. Squirrels In: The animal answer guide. Baltimore: Johns Hopkins University Press. p. 91. ISBN 978-0-8018-8402-3.

Gerlin JR, Forster S, Grafton KF, McClean PE, Rojas-Cifuentes GA. 2007. Analysis of seed zinc and other minerals in a recombinant inbred population of navy bean (Phaseolus vulgaris L.). Crop Science, 47: 1361-1366.

Gomez-Candela C, Bermejo-Lopez LM, Loria-Kohen V. 2011. Importance of a balanced omega 6/omega 3 ratio for the maintenance of health. Nutritional recommendations. Nutr. Hosp., 26L: 323-329.

Harbone JB. 1973. Phytochemical methods. A guide to modern techniques of plant analysis. London: Chapman and Hall Ltd., Pp. 279.

Hoover R. 2001. Composition, molecular structure, and physicochemical properties of tuber and root starches: A Review. Carbohydrate Poly. 45: 253-267.

Igyor MA, Yusuf PA, Sengev IA. 2011. Functional and sensory properties of fermented fura powder supplemented with soy powder. Nigeria Food Journal, 29:113-12.

Ihekoronye A I, Ngoddy P O. 1985. Integrated food science and technology for tropics. London and Basingstoke: Macmillan Publishers, Pp 266-305.

Ijeh CE, Ejike OM Nkwonta, Njoku BC. 2010. Effect of traditional processing techniques on the nutritional and phytochemical composition of African breadfruit (Treculia africana) seeds. Journal of Applied Science Environmental Management, 14(4):169-173.

Ishiwu CN, Tope VA. 2015. Effect of period of fermentation on nutrients of Castor oil seed (Ricinus communis). Direct Research Journal of Agriculture and Food Science 3 (10):178-183.

Iwe MO. 2007. Current trends in sensory evaluation of foods. Enugu: Rejoint Communication Services, Nigeria.

James CJ. 1995. The analytical chemistry of foods. Chapman and Hall Press, New York, pages: 86 - 89.

Jimoh KO, Kolapo AL. 2007. Effect of different stabilizers on acceptability and shelf stability of soy-yoghurt. African Journal of Biotechnology, 6 (8): 1000-1003.

Joel I, Guo-Nong Z. 2008. Screening of stabilizers for peanut milk based set yoghurt by assessment of whey separation, gel firmness and sensory quality of the yoghurt. American Journal of food technology, 3(2): 127- 133.

Knapp S. 2011. Solanum Section geminata (Solanacea). Floral Neotropica Monograh.,84 (1):1-405.

Kumar V, Rani A, Tindwani C, Jain M. 2003. Lipoxygenase isozymes and trypsin inhibitors activities in soy beans as influenced by growing locations. Food chemistry, 83: 79-83.

Li H, Huang W, Wen Y, Gong G, Zhao Q, Yu G. 2010. Antithrombotic activity and chemical characterization of steroidal saponins from Dioscorea zingiberensis C.H., Wright.

Fitoterapia. 81 (8): 1147-56. doi:10.1016/j.fitote.2010.07.016. PMID 20659537. 
Liener JE. 2003. Anti-nutritional factors In: Legumes, Chemistry, Technology and Human Nutrition. Mathews, R. H. (ed.) New York: Marce Delker Inc., Pp. 339-382.

Ndie EC, Okaka JC. 2018. Risk assessment of anti-nutrient consumption of plant foods of South Eastern Nigeria. Journal Food Science Nutrition, 1 (2): 9-12.

Nsofor LM, Osuji CM. 1997. Stability, rheology and chemical properties of soymilk concentrate developed from sprouted soybeans, Journal of Food Science and Technology, 34: $33-$ 40.

Oberlease D. 1973. Phytates. In: Strong F.Ed., Toxicants occurring naturally in foods Washington D.C: National Academy of Science, Pp. 303-307.

Okoye JI, Ene1 GI, Ojobor CC. 2017. Chemical composition and functional properties of sorghum-African yam bean flour blends. Sky Journal of Food Science, 6(2): 21 - 26.

Okoye JI, Nkwocha AC, Ogbonnaya EA. 2007. Functional and sensory properties of cornstarch/soybean flour blends. International Journal of Food and Agricultural Research, 4(2): $263-270$.

Okwunodulu IN, Abasiekong KS. 2015. Rheological behaviour of fortified soymilk from sprouted soybean for complementary feeding: a response surface analysis. Journal of molecular studies and medicine research, 1(1): 26-33.

Okwunodulu IN, Iwe MO Akobundu ENT. 2015. Optimization of tropical storage effects on coagulation time and appearance of un-stabilized micronutrient fortified predigested soymilk for complimentary feeding. Journal of Sustainable Agriculture and the Environment. 16 (2): 343-379.

Okwunodulu IN, Iwe MO, Akobundu ENT. 2017a. Storage stability of un-stabilized predigested soy milk fortified with micronutrients. a response surface approach. Nigerian Food Journals. 35(1): 82-94.

Okwunodulu IN, Iwe MO, Akobundu ENT. 2017b. Optimization of storage effects on selected physico-chemical properties of micronutrient fortified un-stabilized soymilk for complementary feeding using response surface methodology. Interdisciplinary Biosciences 1 (1):11-20.

Okwunodulu IN, Anthony UC, Okwunodulu FU. 2018. Potential mineral exploration of food grade ash from dried empty palm bunch, palm inflorescence and unripe plantain peels: a comparative assessment. Nigerian Journal of Agriculture, Food and Environment. 14(1): 64-73.
Okwu DE, Josiah C. 2006. Evaluation of chemical composition of two Nigerian medicinal plants. African Journal of Biotechnology, 5(4): 357-361.

Onimawo AI, Akubor PI. 2005. Functional properties of food. In: Food Chemistry. Integrated approach with biochemical background. Benin City, Nigeria, Ambik Press Limited, Pp 208-221.

Onimawo A I, Egbekun KM. 1998. Comprehensive Food Science and Nutrition Benin City, Edo State. Ambik Press Ltd. Pp 200-208.

Onwuka GI. 2018. Food analysis and instrumentation. Theory and practices. Revised Edition. Lagos, Nigeria: Naphtali Prints.

Pearson. 1976. Chemical analysis of foods. $7^{\text {th }}$ Edition, London, UK: Church Hill Livingstone, Pp: 72 - 73, 138 - 143, $488-$ 496.

Raff H, Windaier PW, Strang TS. 2004. Human physiology In: Vander, Sherman, Luciens The Mechanism of Body Function. $9^{\text {th }}$ Edition McCCgrem-hill, New York, USA.

Smita K, Kiran SS, Govind BY. 2015. A study on the storage of sterilized soymilk. International Journal of Farm Sciences, 4 (4): 166-179.

STS. 1987. Soya Technology Systems Ltd (Soymilk in Brief - A Case that Makes Scence 11. Gathay Building Singapore: Dhoby Ghaut. No.11-06 0922, 9-47.

Sun H, Xie Y, Ye Y. 2009. Advances in saponin-based adjuvant, Vaccine. 27 (12): 1787-1796. doi:10.1016/j.vaccine. 2009.01.091

Wessling-Resnick M. 2014. Iron In: Ross AC, Caballero B, Cousins RJ, Tucker KL, Ziegler RG, eds. Modern Nutrition in Health and Disease. 11th ed. Baltimore, MD: Lippincott Williams \& Wilkins; 176-88.

Wikipedia, 2019. Amylose. http://en.wikipedia.org/wiki/ Amylose Retrieved 23/5/19.

Yuan S, Chang SK, Liu Z, Xu B. 2008. Elimination of trypsin inhibitor activity and bean flavour in soymilk by consecutive blanching and ultra- high temperature (UHT) processing. Journal of Agricultural Food Chemistry.56 (17): 7957 - 7963. Amankwah EA, Barimah J, Nuamah A K M, Oldham J H, Nnaji C O. 2009. Formulation of weaning food from fermented Maize, Rice, soybean, and fish meal. Pakistan Journal of Nutrition, 8 (11): 1747 - 1752. 